\title{
БНХАУ-ЫН ДАРГА СИ ЗИНЬПИНИЙ ОХУ-Д ХИЙСЭН АЖЛЫН АЙЛЧЛАЛ, ОРОС-ХЯТАДЫН СТРАТЕГИЙН ТҮНШПЭЛИЙН ӨРНӨПТ
}

\section{Товч утга}

А.Нямдопжин *

НХАУ-ын дарга Си Зиньпин 2013 оны 3-р сарын
22-24-ний өдруүдэд ОХУ-д ажлын айлчлал хийсэн нь
дэлхийн опон нийтийн анхаарлыг ихэд татпаа. Өмнөд хөршийн төрийн тэргүун хипийн чанадад хийх анхны айлчпапаа ОХУ-аас эхэпсэн нь Хятадын шинэ удирдагчид дэлхийн улс төр, эдийн засагт эзпэх байр суурь нөлөөгөө бэхжүүпэх үүднээс оросхятадын стратегийн түншлэлээ улам зузаатган бэхжүүпэх гадаад бодпогын чиг шугамыг хэвээр хэрэгжүүпж байгаагаа нотпон харууппаа. Айлчпалын үеэр хоёр улсын хамтын ажилпагааны бүхий п чигпэпийг хамарсан 35 багц баримт бичигт гарын үсэг зурсан нь Үүний ипрэл юм.

Түпхүүр үг: эрчим хуч, нефть, байгапийн хий, худапдаа, хамтын ажилпагаа

ОХУ, БНХАУ-ын эдийн засгийн хамтын ажиплагаа 1999 Оноос эхлэн тогтвортой өсч байгаа бөгөөд япангуяа сүүпийн жилуүдэд хоёр тапын худапдааны эргэлт огцом нэмэгдэж байна. Сүүпийн 20 гаруй жилийн хугацаанд ОХУ, БНХАУ-ын төрийн тэргүунүудийн удаа дараагийн харилцан айлчпал, засгийн газар хоорондын уулзалтын дүнд хоёр улсын хоорондын худалдаа, эдийн засгийн хамтын ажиппагаа амжипттай өргөжин тэлж, тасралтгүй эрчимжин хөгжиж байна.

2013 оны 3-р сарын 22-ноос 24-ний өдруүдэд БНХАУ-ын дарга Си Зиньпин ОХУ-д хийсэн төрийн айлчпапын үеэр хоёр улсын тэргуүн нар худалдаа-эдийн засаг, эрчим хүч, өндөр технологи, байгаль орчин, соёп, аяпал жуупчпалын сапбарт хамтран ажиллах болон олон улсын үйл явдпын талаар санал бодлоо сопилцож, "Бүх

\footnotetext{
${ }^{*}$ А.Нямдопжин-Опон упс судпапын хүрээпэнгийн эрдэм шинжилгээний ахпах ажилтан, доктор (Ph.D)
} 
талын, стратегийн түншлэлийн харилцааг гүнзгийрүүпэн хөгжүупэх, харилцан ашигтай хамтын ажиппагааны тухай хамтарсан мэдэгдэл" 1 д. гарын үсэг зурсан байна.

Шинэ үей̆н орос-хятадын харипцааны үндэс суурь нь их гүрнуудийн нийтлэг ашиг сонирхоп, геополитикийн тэнцвэртэй байдпыг хадгалах, дэпхий дахины упс төр ба эдийн засгийн өөрчпөлтүуд дээр суурипан “сайн хөршийн харилцаа, хамтын ажиппагаа", “харипцан ашигтай хамтын ажиллагаа", “стратегийн түншлэл", "бүх талыг хамарсан иж бүрэн түншлэл"-ийн харилцаагаар тодорхойлогдож байна. Айлчлалын үеэр хоёр упсын хамтын ажиппагааны бүхий $n$ чиглэпийг хамарсан 35 багц баримт бичгүудэд гарын үсэг зурж, худапдаа, эдийн засаг, нефть, эрчим хүч, хөрөнгө оруулаптын салбарт онцгой анхаарап хандуупав. Суупийн 20 жилд хоёр орны хоорондын бараа эргэлт 14 дахин нэмэгдсэн бөгөөд бараа эргэптийн хэмжээ өнгөрсөн онд 88,16 тэрбум ам.доппарт хурсэн ба 2013 онд энэ үзуүлэпт 100 тэрбум, 2020 онд 200 тэрбумд хурнэ гэж үзэж байна. ${ }^{2}$

Дэлхийн хамгийн опон хүн амтай, хамгийн их үйпдвэрпэл хөгжсөн Хятад упсын эдийн засаг хурдацтай өсөхийн хэрээр эрчим хүч, нефть, байгалийн хийн хэрэгпээ ч эрс нэмэгдэж байгаа нь энэ чиглэлээр хоёр орон харипцан ашигтай хамтран ажилпах таатай нөхциийг бүрдуүпж байна. ОХУ байгалийн хий болон модны нөөцөөрөө дэпхийд тэргүүпж, нүүрсний орд газрын нөөцөөр хоёрт, алтны орд газраараа гуравт ордог. Нөөцийн ихэнх хэсэг нь Зуун Сибирь, Алс Дорнодод оршдог нь байршлын хувьд хятадын хэрэгпэгчдэд давуу таптай хэмээн хоёр тап узэж байна. Тэр ч утгаараа айлчлапын хурээнд талууд эрчим хүчний хамтын ажилпагааны тухай нилээд хэдэн чухал баримт бичгүудэд гарын үсэг зурлаа. "Роснефть" компани бопон Хятадын Үндэсний нефтийн (China National Petroleum Corporation) корпорацийн хооронд урьдчилсан төлбөр хийх нөхцөптэйгээр түүхий нефть нийлүупэх үндсэн нөхцпуүдийн тухай хэлэпцээр-Зт гарын үсэг зурж, 2011 оноос Хятад улс руу жилд 15 сая тонн нефть нийлүупж байгаа бөгөөд цаашид 31 сая тонн хүртэл түухий нефть нийлүупэлтийн хэмжээг нэмэгдуупэхээр болжээ. Түүнчпэн "Роснефть" болон Хятадын төрийн банкны хооронд 25 жилийн хугацаатай 2 тэрбум ам.допларын зээлийн гэрээнд гарын үсэг зурлаа. "Мөн "Роснефть" болон Хятадын Үндэсний нефтийн корпорацийн хооронд нуүрс устөрөгч, геологи судпап, хайгуупын сапбарт стратегийн түншлэлийн тухай хэлэпцээрт гарын үсэг зуржээ. "Роснефть" компани нь 1993 онд упсын үйпдвэрийн газар 
болон байгуулагдсан, долоон том нефть боловсруулах компанийг багтаадаг, жилд 50,9 сая тонн нефть олборлох хүчин чадалтай, шатахуун түгээх станцийн тоогоор Орост хоёрт ордог бөгөөд Оросын 41 бүс нутагт 1800 шатахуун түгээх станцтай компани юм. ${ }^{5}$

Оросын "Газпром" компани болон Хятадын Үндэсний нефтийн корпорацийн хооронд Хятадын зүүн чигпэлээр байгалийн хий нийлуүлэх хоолойн төспөөр хамтын ажиппагааны салбарт хамтран ажиппах тухай харипцан ойлгольох санамж бичигт гарын үсэг зурав. Үүний үндсэн дээр "Сибирийн эрч хүч" хэмээх хийн хоолой барьж, 2017 оны сүупээр ашиглаптанд оруупан 2018 оноос Орос улс Хятад упс руу 30 жилийн хугацаатай жипд 38 тэрбум шоо метр хий нийпүүпж эхпэх бөгөөд цаашид жипд 60 тэрбум хүртэп нэмэгдүупэх боломжтой юм. Гэрээний үндсэн нөхциийн эрх үүрэгт энэ оны 7 дугаар сард гарын үсэг зурах ба оны суүпээр урт хугацааны гэрээнд гарын үсэг зурахаар төлөвлөөд байна. 6 Оросын "Газпром" компани нь байгалийн хий ба нефтийн хайгууп, опборполт, тээвэрлэлт, хадгалалт, боловсруулапт хийдэг, дулаан, цахилгаан эрчим хүч нийлүүпдэг, үйлдвэрлэдэг, упсын валютын орлогын 20 хувь, упсын төсвийн 25 хувийг тус тус бүрдуүпдэг эрчим хүчний том компани юм. "Газпром" дэлхийн байгапийн хийн нөөцийн 18\%, орос упсын байгапийн хийн нөөцийн 70\%-ийг эзэмшдэг, дэлхийн байгапийн хий опборполтын $15 \%$, оросын байгапийн хий олборлолтын 78\% оногддог. Ойрх болон Алс дорнодын 30 гаруй оронд хий нийлүупдэг, шатсан байгапийн хий үйлдвэрпэгч, экспортпогч оросын цорын ганц компани бөгөөд дэлхийн шатсан байгалийн хий үйлдвэрпэлийн 5\%-ийг хангадаг байна. ${ }^{7}$

Айлчпалын үеэр хятадын шууд хөрөнгө оруулалтыг дэмжсэн хэд хэдэн гэрээ хэлэлцээрт гарын үсэг зурав. Оросын Зуүн Сибирийг хөгжүупэх, нүүрс олборпох төспийг хэрэгжүүпэх хэлэлцээрт Оросын "En+Group", Хятадын "Shenhua Group" корпораци гарын үсэг зурав. Хятадын Хөгжлийн банкнаас хамтарсан төспийг санхүүжүүлэхэд ойролцоогоор 2 тэрбум ам.доплар гаргах болсон байна. Эдгээр хэлэлцээрийн дагуу нүүрс хайх, опборлох, боловсруупахад хамтран ажиппаад зогсохгүй, түүний дагапдах дэд бүтцийг хөгжүүпэх, тухайлбал, төмөрзам, автозам барих, нефтьолборлох, боловсруулах, төспийн эрчим хүчний хангамжинд зориупан цахилгаан станц барьж байгуулах ажлууд орж байгаа нь Оросын Алс Дорнодын бүс нутгийн хөгжипд түпхэц үзүүпнэ гэж оросын тал үзэж байна. Үүний зэрэгцээ Алс Дорнодын боомтын хүчин чадпыг нэмэгдуупж, Хятад болон 
Азийн бусад орны нүурс хэрэгпэгчдэд нуүрс худалдах, нийлуүпэх ажлыг боловсронгуй болгохоор тохиролцсон байна. Хятад улс дэлхийн нүүрсний хэрэгпээний 50 гаруй хувийг эзэлдэг бөгөөд томоохон нуурс импортпогч орон юм. Хятад упсад том хэмжээний цахилгаан станц баригдаж байгаатай холбоотой нүүрсний эрэлт байнга өсөн нэмэгдэж байгаа бөгөөд хятадын эрчим хүчний 70 гаруй хувь оногдож байна. Хятадад нуүрс нийпүүпэгч гол орнууд бол Австрали, Индонез юм. Оросын нүүрс опборгіогч "En+Group" нь 2008 оноос нуурс олборлож байгаа бөгөөд 4 тэрбум гаруй тонн нүүрсний нөөш бүхий орд газрыг эзэмшдэг, Зүүн Сибирь болон Казакстан дахь орд газруудаасаа жипд 50 гаруй сая тонн нүүрс опборподог, 2012 оноос эхлэн Хятад болон Азийн бусад орон руу нуурс нийлуүпж байгаа компани юм. ${ }^{8}$

ОХУ-ын Эрчим хүчний яам болон Хятадын эрчим хүчний хороо нефть, байгалийн хийн үйлдвэрпэлд хамтран ажилпах гэрээнд гарын үсэг зурав. Айлчпалын үеэр нефть хайх, олборлох, түухий нефть худапдах сапбарын хүрээнд Тяньжиний нефть боловсруулах үйлдвэрийг барьж, ашигпаптанд оруулах хамтын ажилпагааны хэлэлцээрт гарын үсэг зурсан байна. Уг төслийг хэрэгжуупэхийн тупд Оросын "Роснефть" компани 49\%, Хятадын нефтийн корпораци 51\%-ийн эзэмшилтэйгээр Орос-Хятадын хамтарсан нефть-химийн компанийг байгуупаад байна. Энэ хамтарсан үйлдвэрийг 2015 он гэхэд барьж дуусахаар төлөвлөж байгаа бөгөөд тус үйлдвэр нь жилд 13 сая тонн нефть боловсруупж түүнээс 9 сая тонн нь оросын түухий нефть эзпэх юм.

"Роснефть" болон "Синопек" корпорацийн хооронд бүх талын хамтын ажилпагааны тухай протокопд гарын үсэг зурсан байна. Уг протоколын дагуу хоёр тал Сахалин-3 төслийн ажлыг боловсронгуй болгох талаар тохиролцов.

Оросын "Русап" компани, Хятадын хөнгөн шагааны "Chalсо" корпорацийн хооронд хөнгөн цагааны хүдэр боловсруулалт, хөнгөн цагаан үйлдвэрлэлийн шинэ технологийн сапбар дахь эрдэм шинжипгээ, судапгааны төспийн хамтын ажиппагааны харипцан ойлголцох санамж бичигт гарын үсэг зурсан байна.9 "Русап" компанид дэлхийн хөнгөн цагаан үйлдвэрпэлийн 10\% оногддог, 19 оронд салбартай, жипд 4,7 сая тонн хөнгөн цагаан үйлдвэрпэх хүчин чадаптай том компани юм. Европ, Хойд Америк, Зүүн өмнөд Азийн орнуудын зах зээлд бүтээгдэхүүнээ борлуупдаг бөгөөд Хятад упс руу 100 мянга гаруй тонн хөнгөн цагаан нийлуүпдэг байна. 2012 оны 4 дүгээр сард "Русап" компани нь хятадын машин 
үйлдвэрпэлийн NORINCO корпораци хамтран Хятадад North United Aluminium хэмээх хамтарсан үйлдвэр байгуулах ажлыг эхлээд байгаа бөгөөд Хятадын зах зээпд хөнгөн цагаан, хайлш бусад өнгөт метапл нийлуүпэлтийн ажлыг гүйцэтгэх юм. "Русап" компани нь тус хамтарсан үйпдвэрээр дамжуупан хятадын зах зээл дэх хөнгөн цагааны борлуупаптыг жилд 200-300 мянган тонноор нэмэгдуупэх боломжтой гэж найдаж байгаа юм.

Орос, Хятад хоёр орны цэрэг техникийн салбарын уламжлалт хамтын ажиппагаа нь стратегийн хамтын ажиплагааны түвшний нэг чухал хэпбэр юм. Айлчлапын үеэр БНХАУ-ын дарга Си Зиньпин Оросын Батпан хамгаалах яам ба Хопбооны зэвсэгт хүчний байлдааны төвтэй танилцан, ОХУ БНХАУ-д "Пада" ангиллын дизепийн хөдөлгүуртэй 4 шумбагч онгоц барих, 24 ширхэг Су-35 байлдааны онгоц нийпүүпэх гэрээнд гарын үсэг зурсан байна.

Хоёр тал хоёр орны соёп, хүмүүнпэгийн салбарын хамтын ажиллагааг өргөжүүпэх талаар хэд хэдэн баримт бичигт гарын үсэг зурав. БНХАУ-ын дарга Си Зиньпиний санаачпагаар 2014-2015 оныг ОХУ болон БНХАУ-ын хооронд залуучуудын солилцооны жил болгохоор тохиропшсон байна. Энэ уеэр "Хип, хязгааргүй дэлхий" олон улсын аяпап жуупчпалын нэгдэл ба Гуандун мужийн аяпал жуупчлапын газрын хооронд арипжааны бус түншлэлийн хамтын ажиппагааны тухай хэлэпцээ, Санкт-Петербургийн эдийн засгийн их сургууль, Хятадын аяпап, жуупчлалын хүрээпэн, Хэйлунзянийн их сургуупийн хооронд аялап жуупчлал, дээд боловсрол, эрдэм шинжипгээний сапбар дахь хамтын ажиппагааны тухай хэлэлцээр, Орос-Хятадын клуб ба Хятадын Хайнань мужийн аяпал, жуулчпап хөгжүүпэх хорооны хооронд стратегийн хамтын ажиплагааны хэлэлцээрт тус тус гарын үсэг зурав. Өмнөх жилуүдэд зохиогдсон соёл, урлаг болон боловсролын томоохон арга хэмжээнуүд нь хүмүүнпзгийн сапбарын хамтын ахииппагааг гүнзгийруүпэхэд нөлөөпсөн гэж талууд үзэж байна. Тухайлбап, хятад, орос хэлний жилуүд болж өнгөрсний зэрэгцээ, 2012-2013 оны “Хятад дахь оросын аяпап жуупчпалын жил"-ийн хүрээнд "Бээжин-Москва авто аяпал”, "Сайн байна уу, Орос орон”, "1000 хятадын жуулчид Орост аяпж байна" зэрэг 200 гаруй арга хэмжээ зохиогдоод байна. 2015 гэхэд хоёр тал, хоёр орны жуупчдын тоог 5 саяд хүргэхээр төлөвлөж байна. ${ }^{10}$

Түүнчпэн "Оросын дуу хоопой" радиостанц, хятадын "Жэнминьван" интернет-портал болон "Хятадын опон улсын радио"-гийн хооронд мэдээлпийн хамтєн ажиплагааны тухай хоёр 
хэлэпцээрт гарын үсэг зурав. "Оросын дуу хоолой" радиостанц нь 1929 оноос үйл ажиппагаагаа явуупж байгаа, дэлхийн 31 хэл дээр нэвтруупэг бэлтгэн явуупдаг хэвлэп мэдээлпийн том компани юм. Энэхуу хамтын ажиппагаа нь хоёр орны найрамдап, нөхөрпөл, түух, хэл, соёлыг түгээн дэлгэруүлэх, суртапчилахад чухап уүрэгтэй гэж тапууд үзэж байна. ${ }^{11}$

Хоёр тал НҮБ, “Их-20”, БРИКС, Шанхайн хамтын ажиплагааны байгууппагуудын хурээнд нягт уялдаатай ажиппадаг бөгөөд хоёр орны хамтын ажиплагаа нь Ази-Номхон далайн бүс нутгийн аюулгүй байдпыг бэхжуупэхэд чухал уүрэгтэй. НҮБ-ын Аюулгүйн зөвпөлийн байнгын гишүун орон, дэпхийн хоёр том эдийн засагтай орнуудын хувьд стратегийн түншийн харипцаа нь зөвхөн хоёр талд бус, олон упсын хэмжээнд чухал ач холбогдоптой талаар хоёр орны удирдагчид уулзаптын үеэр онцлон тэмдэглэсэн байна.

Монгоп упс нь тус хоёр хүчирхэг гүрний дунд оршдог, эдийн засгийн хувьд хоёр хөршөөсөө хамаараптай байдгийн хувьд ууп уурхай, дэд бутэц, эрчим хүч, газрын тос, хөдөө аж ахуй зэрэг эдийн засгийн гоп сапбарууд дахь хамтын ажилпагааг хоёр хөрштэйгөө өргөжуүпэн хөгжуүпэх, Монгоп, Хятад, Орос гурван упсыг хопбосон төспуудийг хэрэгжүупэх, хөрш хоёр орон ОХУ, БНХАУ-ын хооронд байгуупах газрын тос, байгалийн хий, цахилгаан дамжуулах шугамын төспууд зэрэг хэрэгжүупэхээр тохиропцсон дээрх төспуудэд Монгоп Упс орольох сонирхолтой байгаа бөгөөд энэ тухайгаа ч монголын тап энэ оны 4-р сард БНХАУ-ын Хайнань мужийн Боао хотод болсон "Азийн төлөөх Боаогийн чуулга уупзапт"-ын үеэр БНХАУын дарга Си Зиньпинтэй уулзахдаа илэрхийлсэн.

Нефтийн нийлуупэптээ нэмэгдуупэх хүрээнд ОХУ-аас БНХАУ-ын баруун хэсэг рүү төмөр зам тавихдаа үр ашигтай замаар тээвэрлэх асуудап тавигдаж байна. Анхаарап татсан нэг асуудап бол Сквородино-Мохэ, Дорнод-Сибирь-Номхон дапайн чиглэлийн дамжуупах хоолойн хучин чадлыг нэмэгдуулэх, Казахстанаар дамжих шинэ чиглэл бий болгох зэрэг нефть тээвэрлэх гурван хувилбар яригдаж байгаагийн нэг нь Монгол улсын нутгаар дамжуупж болох тухай Транснефтийн төлөөпөгчийн мэдэгдэл юм. 7 сая тонн нефть Казахстаны Атасу-Апашаныкоу нефтийн хоопойгоор дамжуупан тээвэрпэхэд экспортын татварт Казахстанд 80 тэрбум руб. төлөх юм. Энэ нь 1 тонн нефть 420,6\$ болж байна. Транснефтийн байр суурийг аваад үзэхэд Хятадын баруун хэсэг руу төмөр замаар Монгоп улсын нутгаар транзитаар тээвэрпэж болох бөгөөд өмнө нь нийт 7 сая тонн нефтийн 2 сая тонныг Забайкапьск-Манжуурын 
хилээр Хятадын Дачинд, 5 сая тонн нефтийг Наушкийн хилийн боомтоор Монгоп улсын нутгаар транзитаар тээвэрлэж байсан туршлага байгаа ба монголын тал тээвэрлэлтийн хөнгөлөлт үзуүпж байсан учир боломжтой гэж үзэж байна. Монголын чиглэл ачаалап багатай нийт хүчин чадлынхаа 20\%-ийг ашигладаг. Хэрэв Монголын нутгаар дамжуупахаар болбол хоопойны уртыг 1000 орчим кипометрээр багасгаж, нэпээд зардап хэмнэх боломжтой юм. Энэхуү чиглэп нь нөгөө тапаасаа Сибирь, Алс Дорнодыг хөгжүупэх ОХУ-ын нийгэм-эдийн засгийн бодлоготой нийцэж байгаа бөгөөд Эрхүу мужийг хөгжүүпэх боломж бүрдэнэ гэж үзэж байна. Харин "Роснефть" энэ хувипбарын хувьд ашиггуй гэсэн байр суурьтай байгаа юм. Учир нь Эрхуу мужийн Мегет станц нь Казахстанаас байршлын хувьд хоп гэж үзэж байна.

Монгоп улсын хувьд энэхүу транзит тээврээс их хэмжээний ашиг опох, эрчим хүчний эх үүсвэртэй бопж, нүүрсний хэрэгпээгээ эрс багасгах, цахипгааны нөөцтэй болохын зэрэгцээ Оюутолгой, Тавантолгой зэрэг томоохон төслүүдийн зардпыг хэмнэх зэрэг олон эерэг үр дагавартай юм.

\section{ДУГНЭПТ}

БНХАУ-ын дарга Си Зиньпиний ОХУ-д хийсэн айпчпап нь Орос, Хятадын худапдаа, эдийн засгийн харипцааны хөгжил дээд түвшинд хүрч, стратегийн түншлэпийн хэлбэр нь хоёр талын болон бүс нутгийн хамтын ажилпагаанд хэвээр хадгалагдан шинэ агуулгаар баяжиж, упам өргөжиж байгааг харууппаа. Хоёр орны эрчим хүчний салбарын хамтын ажиплагаa өргөжин, ОХУ-аaс БНХАУ руу нийпүупэх нефть, байгапийн хийн хэмжээг нэмэгдуупэхээр тохиролцон урт хугацааны хамтын ажиллагааны баримт бичгуүдэд гарын үсэг зурлаа. ОХУ, БНХАУ-ын хооронд байгуулах газрын тос, байгалийн хий, цахилгаан дамжуулах шугамын төспуүд зэрэг хэрэгжүүпэхээр тохиропцсон дээрх төспуүдэд Монгоп Упс оролцох боломж гарч ирэх магадлал байна.

\section{АШИГПАСАН МАТЕРИАЛ:}

1. Совместное заявпение Российской Федерации и Китайской Народной Республики о взаимовыгодном сотрудничестве и угпублении отношений всеобъемлюшего партнёрства и стратегического взаимодействия. 22 марта 2013 г. Москва.

2. Обзор российско-китайской торговли в 2012 г.

http://www.russchinatrade.ru/assets/files/ru-ru-cn-coop/ru_ 
ch_trade_2012.pdf

3. Соглашение об основных усповиях поставок сырой нефти на усповиях предоппаты между Открытым акционерным обшеством "Нефтяная компания "Роснефть" и Китайской национальной нефтегазовой корпорацией; 22 марта 2013 г. Москва.

4. Российско-китайская нефть. Эксперт. 20 июн 2013.

http://expert.ru/2013/06/20/rossijsko-kitajskaya-neft/

5. Роснефть сегодня. http://www.rosneft.ru/about/

6. Газпром и Роснефть подписали согпашения с китайской CNPC.// Вгпяд. Деповая газета. 22 марта 2013.

http://www.vz.ru/news/2013/3/22/625615.html

7. О газпроме. http://www.gazprom.ru/about/

8. Банк развития Китая будет финансировать проекты добычи угля в России.

http://polcoaldex.pl/ru/wegiel/913-chi\%C5\%84ski-bank-rozwoju-sfinansuje-projekty-wydobycia-w\% $44 \% 99$ gla-w-rosji.html

9. РУСАЛ и Chalco усипят сотрудничество в алюминиевой отрасли.

http://www.rusal.ru/press-center/press-releases.aspx?

dyncont $=8475$

10.0 гуманитарных обменах Китая и России. Китайский информационный центр.

http://russian.cri.cn/1143/2013/03/19/1s461455.htm

11. Сайт "Жэньминьван" и радиостанция "Гопос России" подписапи соглашение о сотрудничестве.

http://russian.people.com.cn/31519/8179820.html

\section{Abstract:}

Chinese President Xi Jinping visited Russia on a working visit. The talks which attracted worldwide attraction were held in Moscow from 22 to 24 March 2013. During the talks, Russia and China signed 35 agreements on cooperation. The two leaders discussed trade and economic cooperation in the fields of the high-tech, environmental protection, culture and tourism. During the visit, the two leaders signed a joint statement between China and Russia on mutual cooperation and deepening the relations of a comprehensive strategic partnership of cooperation. 